Revue de sciences sociales sur les arts, la culture et les idées

4 | 2019

Autonomies des arts et de la culture

\title{
Autonomies of Art and Culture
}

Symbolic Goods Meet the State and the Market

Autonomies des arts et de la culture. Les biens symboliques face à l'État et au marché

Autonomias del arte y la cultura. Los bienes simbólicos frente al Estado y al mercado?

Jérôme Pacouret and Mathieu Hauchecorne

Translator. Delaina Haslam

\section{(2) OpenEdition}

\section{Electronic version}

URL: http://journals.openedition.org/bssg/329

DOI: $10.4000 /$ bssg.329

ISSN: 2490-9424

Publisher

Presses universitaires de Vincennes

\section{Electronic reference}

Jérôme Pacouret and Mathieu Hauchecorne, "Autonomies of Art and Culture", Biens Symboliques / Symbolic Goods [Online], 4 | 2019, Online since 27 June 2019, connection on 04 March 2021. URL: http://journals.openedition.org/bssg/329 ; DOI: https://doi.org/10.4000/bssg.329 


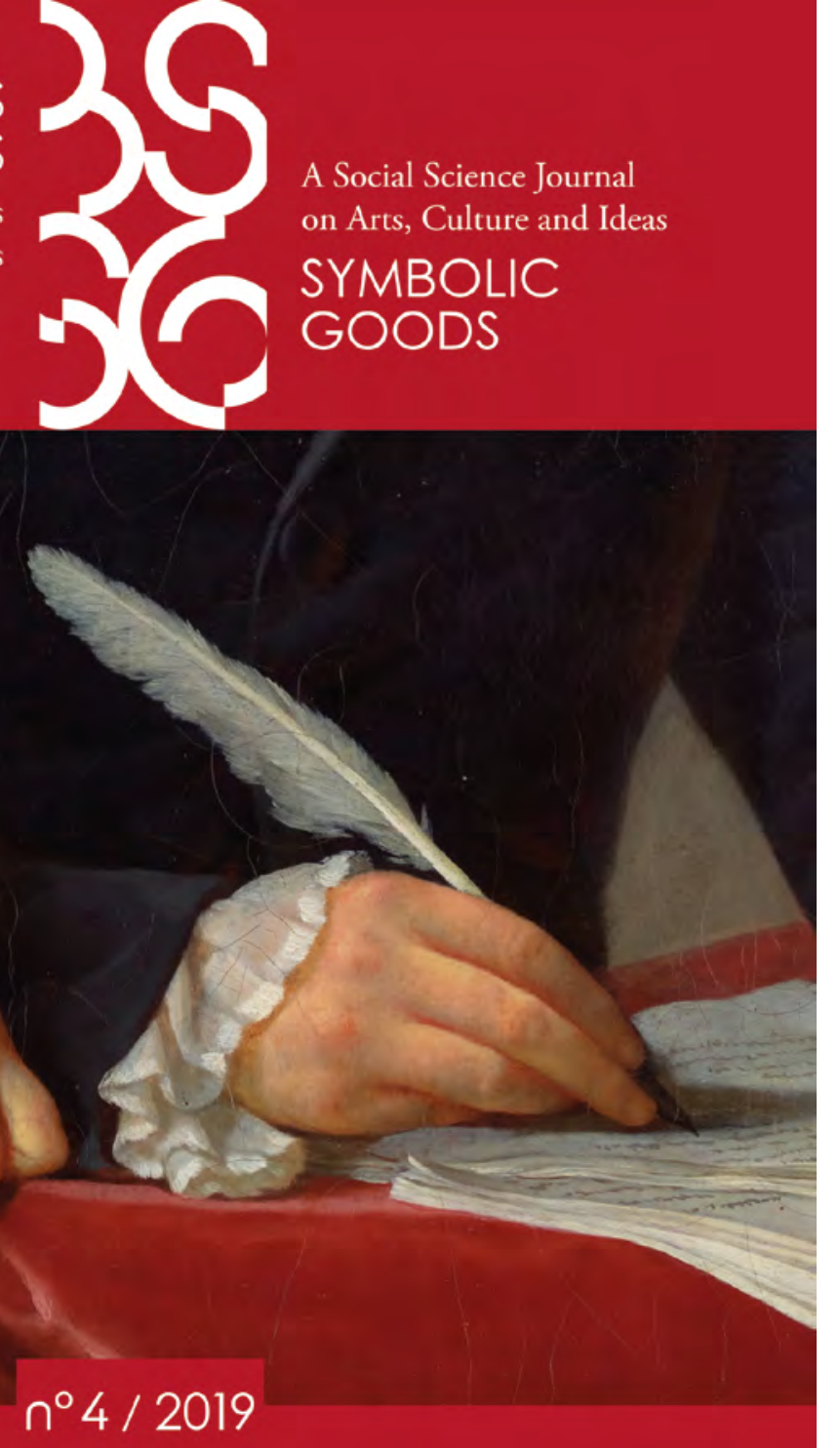

Autonomies des arts et de la culture Autonomies of Art and Culture 


\title{
Autonomies des arts et de la culture \\ Les biens symboliques face à l'État et au marché ${ }^{1}$ \\ Autonomies of Art and Culture \\ Symbolic Goods Meet the State and the Market $^{1}$
}

\author{
Jérôme Pacouret | Mathieu Hauchecorne \\ traduction | translation \\ Delaina Haslam
}

Dans les travaux de sciences sociales consacrés à l'art, à la culture, aux sciences et aux idées, le terme d'« autonomie » bénéficie d'une fortune singulière. II peut être mobilisé pour décrire, d'un point de vue historique, la différenciation de champs fonctionnant selon des logiques propres, comme celui de l'art (Moulin 1969 ; Sofio 2016), de la littérature (Bourdieu 1971; 1998 [1992] ; Viala 1985) ou du

1. Ce dossier est issu d'une journée d'étude organisée le 12 février 2015 par le réseau thématique 27 ([RT27] sociologie des intellectuels et de l'expertise savoir et pouvoir) de l'Association française de sociologie, en partenariat avec le réseau thématique 14 ([RT14] sociologie des arts et de la culture). Nous remercions les participant $\cdot$ e.s à cette journée et les membres des RT 14 et 27 qui ont pris part à son organisation, et tout particulièrement Odile Henry qui avait notamment contribué à la rédaction de l'appel à communication initial. Le comité scientifique de cette journée d'étude était constitué de Boris Attencourt, Annabelle Boissier, Thibault Boncourt, Frédéric Chateigner Corinne Delmas, Thomas Depecker, Mathieu Hauchecorne, Emmanue Henry, Odile Henry, Laurent Jeanpierre, Jérôme Pacouret, Marie Sonnette, Arnault Skornicki, Séverine Sofio et Adrien Thibault.
In social science research on art, culture, science and ideas, the term "autonomy" has a unique role. It can be used from a historical point of view to describe the "autonomization" of a field, such as the artistic (Moulin 1969; Sofio 2016), literary (Bourdieu 1985; 1996; Viala 1985) or that of cinema (Duval 2016) - this is generally vis-à-vis other fields such as the religious, the political, or the economic. Since the autonomy of a field is always relative, the

1. This issue grew out of a workshop organized in February 2015 by network 27 (sociology of intellectuals and expertise) of the French sociological association, in association with network 14 (sociology of art and culture). We would like to thank those who attended the workshop as well as the members of networks 14 and 27 who took part in its organization-especially Odile Henry who contributed to the conception of the original project. The scientific committee was composed of Boris Attencourt, Annabelle Boissier, Thibault Boncourt, Frédéric Chateigner, Corinne Delmas, Thomas Depecker, Mathieu Hauchecorne, Emmanuel Henry, Odile Henry, Laurent Jeanpierre, Jérôme Pacouret, Marie Sonnette, Arnault Skornicki, Séverine Sofio and Adrien Thibault. 
cinéma (Duval 2016). Ces processus d'autonomisation s'opèrent généralement vis-à-vis d'autres champs comme les champs religieux, politique ou économique. L'autonomie d'un champ étant toujours relative, cette notion et celle d'hétéronomie sont également employées pour analyser les logiques capitalistes, les interventions d'État et les divisions sociales qui structurent les activités culturelles (Champy 1996 ; Moulin 1969 ; Bourdieu 1998 [1992] ; Kréfa 2013), ainsi que l'engagement de leurs acteurs dans des luttes politiques (Sapiro 2009). À un autre niveau, le couple autonomie/hétéronomie sert à étudier les logiques d'action et les relations se manifestant au sein d'un champ autonomisé. Ces termes peuvent soit s'appliquer à un groupe, comme lorsqu'on parle de l'autonomie d'une profession artistique (Sapiro 2006), soit caractériser la position (plus ou moins autonome) d'un agent au sein d'un espace donné (Bourdieu 1998 [1992]). La notion d'autonomie est encore invoquée pour justifier ou critiquer des analyses internalistes d'œuvres d'art (Raynaud 1999). Elle a été mobilisée pour étudier les relations entre des champs culturels nationaux (Casanova 1999) et l'émergence de champs transnationaux (Sapiro 2013). Elle peut enfin être considérée comme un mythe à dépasser, comme lorsque les travaux de Science Studies mettent en doute l'autonomie de la science en reconstituant le tissu des liens et relations de dépendance à l'intérieur desquels l'activité scientifique est encastrée (Latour 1984).

Ces usages de la notion d'autonomie distinguent doublement la sociologie des biens symboliques d'autres domaines d'étude. $\mathrm{Si}$ d'autres domaines de la sociologie ont également recours à ce terme, il n'y est en effet pas utilisé avec la même fréquence, et renvoie à des significations souvent peu éloignées de ses usages ordinaires ou du sens qu'il a pu prendre dans les domaines philosophique ou politique. De manière révélatrice, une grande partie des dictionnaires de sociologie générale ne lui consacrent pas d'entrée ${ }^{2}$. Quand il y

2. C'est par exemple le cas de Boudon \& Bourricaud (2011), Boudon et al. (1999) ou Bruce \& Yearley (2006). notions of autonomy and heteronomy are also used to analyse how capitalism, the State and social divisions structure cultural activities (Champy 1996; Moulin 1969; Bourdieu 1996; Kréfa 2013), as well as the involvement of their representatives within political struggles (Sapiro 2009). The concepts of autonomy and heteronomy are also used in order to study the logics of action and relations that manifest within the autonomized field. These terms can apply to a group as a whole, such as when we talk about the organizational autonomy of an artistic profession (Sapiro 2006), or conversely they may be employed to characterize the degree of autonomy which characterizes the position of an agent within a given space (Bourdieu 1996). The notion of autonomy is also used to justify or criticize internalist analysis of works of art (Raynaud 1999). It was employed to study the relations between national cultural fields (Casanova 1999) and the emergence of transnational fields (Sapiro 2013). Lastly, it can be used in the context of a myth to debunk, such as the way works in science studies have thrown the autonomy of science into doubt by reconstituting the fabric of connections and relations of dependence within which scientific activity is embedded (Latour 1984).

These uses of the concept of autonomy clearly distinguish the sociology of symbolic goods from other areas of study. While other subfields of sociology also make use of the term, they do so less frequently, and with meanings that are often close to the ordinary sense of the term or in the sense that it has taken on in philosophy or politics. It is telling that some dictionaries of general sociology have no entry for the term ${ }^{2}$. When it does appear, it is generally to give either a definition that psychologizes

2. For example, this is the case for Boudon \& Bourricaud (2011), Boudon et al. (1999) and Bruce \& Yearley (2006). 
figure, c'est généralement pour retenir une définition psychologisante de l'autonomie - comme maîtrise de soi, ou comme capacité à échapper aux normes sociales environnantes - à laquelle peut s'ajouter l'acception politique du terme comme autogouvernement ${ }^{3}$. Le Dictionnaire de sociologie coordonné par André Akoun et Pierre Ansart (1999) mentionne également le sens que le terme peut prendre au sein de la sociologie marxiste pour décrire l'« autonomie relative » de l'État vis-à-vis de l'infrastructure économique, ainsi qu'une acception plus épistémologique du terme lorsqu'il est question des faits sociaux comme domaine d'étude séparé. Cet état des lieux contraste avec les significations très spécifiques prises par le terme dans les travaux de sciences sociales consacrés aux biens symboliques.

L'ambition de ce dossier est de démêler les significations multiples de la notion d'autonomie en sociologie de la culture, de l'art et des idées ; de donner un aperçu de ses usages ; et de considérer les questions qu'ils soulèvent, tout particulièrement dans la théorie des champs mobilisée par la plupart des contributeurs et contributrices à ce numéro. Si les articles de ce dossier proposent des études de cas issues de divers domaines (journalisme, artisanat d'art, édition, musique) et des usages à chaque fois différents de la notion d'autonomie, l'article de Gisèle Sapiro, plus épistémologique, présente une synthèse raisonnée des définitions de l'autonomie proposées par différentes traditions sociologiques et opère une confrontation des programmes de recherche sur les arts et la connaissance qui leur sont associés. autonomy (here understood as self-control, or as the capacity to escape prevailing social norms) or the political meaning of the term denoting self-government ${ }^{3}$. The Dictionnaire de sociologie, edited by André Akoun and Pierre Ansart (Le Seuil/Le Robert, 1999), also includes the meaning that the term can have within Marxist sociology when it is a matter of 'relative autonomy' of the State vis-à-vis that of the economic infrastructure, as well as a more epistemological meaning concerning social realities as a field of study that can be autonomized. This situation contrasts with the very specific meanings that the term has taken on within social science work focused on symbolic goods.

The ambition of this issue is to give an overview of the uses of the concept of autonomy in the sociology of culture and ideas and to disentangle its multiple meanings. It also aims to draw a line under the issues surrounding autonomy and to appreciate what they tell us about the spaces of symbolic production and about social science in general. The articles in this issue are case studies using various conceptions of autonomy in different contexts (journalism, artistic handicrafts, publishing, music), while the more epistemological article by GS offers a considered review of the definitions of autonomy as proposed by different theoretical traditions in the sociology of arts and knowledge. 


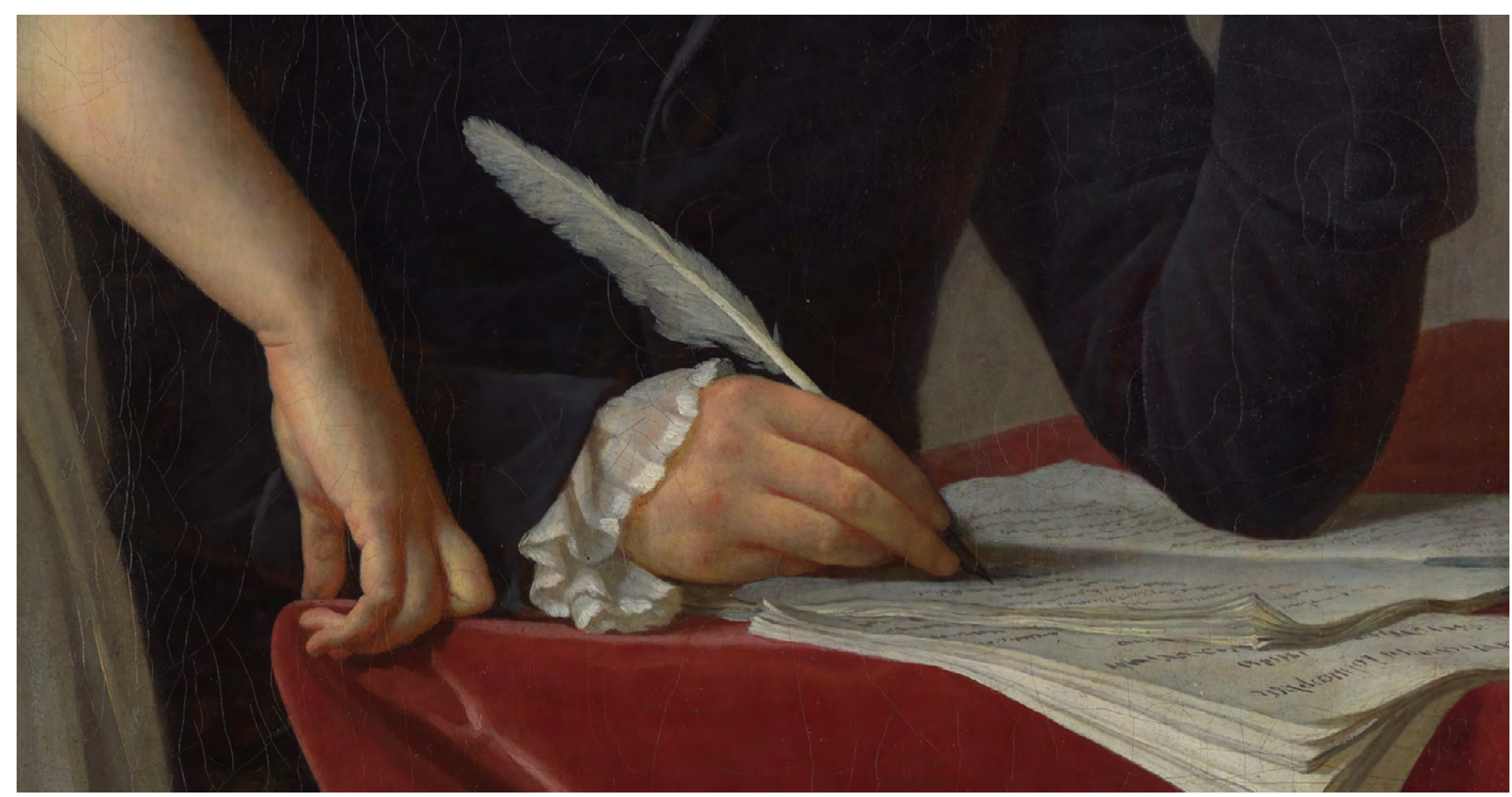

Jacques Louis David, « Antoine Laurent Lavoisier (1743-1794)

Jacques Louis David "Antoine Laurent Lavoisier (1743-1794) et sa femme (Marie Anne Pierrette Paulze, 1758-1836) », 1788 (détail) Source : Metropolitan Museum of Art, New York. and His Wife (Marie Anne Pierrette Paulze, 1758-1836)," 1788 (detail). Source: Metropolitan Museum of Art, New York. 


\section{Usages savants, usages indigènes de la notion d'autonomie}

La fréquence relative des usages du terme d'autonomie dans l'étude des biens symboliques se double de la multiplicité des significations, parfois contradictoires, qui lui sont associées. Cette pluralité de significations, parfois source de confusion, renvoie en premier lieu à une pluralité de traditions théoriques. Dans son article, Gisèle Sapiro considère plus particulièrement trois d'entre elles. En sociologie des professions, d'abord, le terme prend un sens proche de sa signification politique d'autodétermination collective et renvoie à la capacité des membres d'une profession à la réguler et à la reproduire. Ensuite, les analyses marxistes des productions culturelles déclinent la problématique plus générale des rapports entre l'infrastructure économique et la superstructure politique, religieuse et culturelle, dont l'autonomie à l'égard de l'économie ne peut être que relative. Enfin, l'analyse bourdieusienne de l'autonomie des champs apparaît quant à elle inséparable de son analyse de la différenciation sociale. Ces formes d'autonomie peuvent s'entretenir mutuellement, par exemple quand l'émergence d'un corps de spécialistes, constitutif d'un champ autonome, se traduit par l'institutionnalisation d'une profession à part entière comme ce fut par exemple le cas pour le journalisme. Mais l'autonomie d'un groupe professionnel et celle d'un champ ne vont pas toujours de pair. Dans sa contribution au dossier, Myrtille Picaud montre ainsi comment, à Berlin, le champ des salles de musique peut présenter un degré d'autonomie (au sens bourdieusien) plus grand qu'à Paris, malgré une autonomie professionnelle plus réduite des programmateurs et programmatrices de salles.

Si l'entrecroisement de ces usages théoriques est parfois source de confusion, celle-ci est redoublée par les significations indigènes du terme d'autonomie. En effet, l'autonomie est également une catégorie mobilisée par les agents, en particulier pour défendre

\section{The Concept of Autonomy and its Scholarly and Vernacular Uses}

The term autonomy is frequent in the study of symbolic goods, but it is also complicated by the multiplicity of sometimes contradictory meanings associated with it. This plurality of meanings, which is sometimes the source of confusion, is first of all a result of a plurality of theoretical traditions. Gisèle Sapiro's article considers three of these in greater detail. In the sociology of professions, the term adopts a meaning close to its political sense of collective selfdetermination and implies the capacity of members of a profession to regulate and reproduce it. Marxist analysis of cultural productions presents the more general problem of relations between the economic infrastructure and the political, religious, and cultural superstructure, in which autonomy with regard to the economy can only be relative. Finally, Bourdieusian analysis of the autonomy of fields would in turn appear inseparable from his analysis of social differentiation. These forms of autonomy can sometimes converge, for example when the emergence of a body of specialists that constitutes an autonomous field results in the institutionalization of a profession in its own right as was the case, for example, for journalism. However, we do not always see such parallels. In her contribution to the dossier, for instance, Myrtille Picaud shows how Berlin's live music venues enjoy a greater degree of autonomy (in the Bourdieusian sense) than their Parisian counterparts despite the fact that bookers have less professional autonomy in Berlin.

If the intersection of these theoretical uses of "autonomy" is sometimes a source of confusion, this is only increased by vernacular meanings of the term. Autonomy is indeed a category employed by agents, notably in order to defend the autonomy 
l'autonomie de la vie intellectuelle ou culturelle face à l'entremise de l'État ou d'intérêts économiques. Ainsi, comme le montre Sophie Noël dans ce dossier, les éditeurs critiques ont pu tenter de défendre leur statut en mobilisant cette catégorie, au point de la préférer parfois à celle - proche - d'« indépendance ", trop galvaudée à leurs yeux et pouvant être réduite à sa signification économique. Ce terme d'indépendance est d'ailleurs mobilisé, parfois en association avec celui d'autonomie, pour défendre le « cinéma indépendant » ou, dans le domaine de la presse, l'« indépendance » des rédactions vis-à-vis des actionnaires et de la direction.

Ces usages indigènes aussi bien que savants du terme d'autonomie ne sont en outre pas totalement dissociables. Comme le fait remarquer Gisèle Sapiro dans sa contribution, le concept d'autonomie que mobilise la sociologie des professions « reprend la définition indigène de l'autonomie professionnelle ». Inversement, les acteurs et actrices des espaces de la production culturelle peuvent s'approprier certaines analyses issues de la sociologie de la culture. Les usages politiques de la notion d'autonomie sont parfois opérés par les chercheurs et les chercheuses eux/ellesmêmes. Pierre Bourdieu a ainsi fait de l'autonomie des champs de production culturels et scientifiques non seulement un fait empirique à étudier mais aussi une cause à défendre face aux logiques néolibérales (Bourdieu 1998). Cela soulève la question des implicites normatifs ou politiques qui sous-tendent certains

usages de la catégorie d'autonomie en sociologie de la culture.

\section{Mesurer l'autonomie}

Dans quels cas peut-on parler d'autonomisation d'un champ ou d'un domaine d'activité ? Peut-on distinguer des degrés plus ou moins élevés d'autonomie ? À quoi les mesure-t-on ? Comme le présentent les articles de ce dossier, cette question peut of intellectual or cultural life in the face of State intervention or economic interests. As Sophie Noël's contribution to this issue shows, the category of autonomy has sometimes been taken up by publishers to defend their status, sometimes preferring "autonomy" to the close concept of "independence" which is too much of a cliché for them, and which can be reduced to its economic significance. The term "independence" is also used, sometimes in association with that of autonomy, to defend "independent cinema" or, in the press, the "independence" of what is written vis-à-vis shareholders and management.

It can also be difficult to separate these vernacular and scholarly uses of the term autonomy completely. As Gisèle Sapiro notes in her contribution, the concept of autonomy employed by the sociology of professions "incorporates the vernacular definition of professional autonomy." Conversely, professionals in the cultural spheres can appropriate certain analyses produced by the sociology of culture. Researchers themselves may also make political use of the concept of autonomy. Pierre Bourdieu for instance made the autonomy of the fields of cultural and scientific production not only an empirical fact to be studied but also a cause to defend in response to neoliberalism (Bourdieu 1998), which then raises the question of the normative or political implicit that underlies certain uses of the category of autonomy in the sociology of culture.

\section{Measuring Autonomy}

Under which circumstances can we talk about the autonomization of a field or area of activity? Is it possible to distinguish greater and lesser degrees of autonomy? What do we measure them against? As the articles in this dossier show, this issue can be viewed on 
être envisagée à différents niveaux : celui du groupe (champ, profession...) dans son ensemble, celui des individus au sein de ce groupe, ou celui des productions symboliques elles-mêmes.

On peut tout d'abord s'intéresser aux formes institutionnelles de l'autonomie. Dans la théorie des champs, celles-ci renvoient à trois dimensions : l'apparition d'un groupe spécialisé dans la production des biens en question; la constitution d'instances de consécration spécifiques ; la formation d'un marché des biens symboliques (Bourdieu 1971a). Ces trois dimensions prennent toutefois des contours différents selon les activités considérées, comme l'expriment les différentes études de cas réunies ici. Les marchés associés aux champs de production symbolique peuvent être des marchés au sens ordinaire du terme (où s'échange un produit auquel est associé un prix monétaire) ou dans un sens plus métaphorique. Par contraste avec les activités littéraire, cinématographique et journalistique, la production scientifique est par exemple très peu dépendante de la vente d'œuvres. Le terme de « marché » peut aussi être employé pour analyser des échanges non monétaires, comme dans le cas du champ religieux ou « marché des biens de salut » (Bourdieu 1971b) En outre, même quand le terme de « marché » est à prendre au sens ordinaire de mise en relation d'une offre et d'une demande, les marchés de biens symboliques présentent des spécificités qui les distinguent à la fois les uns des autres, et des marchés de biens non culturels. Dans ce dossier, Julien Duval montre bien que l'autonomisation des champs journalistique et cinématographique s'est, à l'image du champ littéraire, manifestée à travers l'émergence d'un pôle de production restreinte où les logiques économiques de maximisation des ventes ou du profit ne sont pas en mesure de prévaloir. On retrouve ainsi au sein du champ journalistique une opposition entre une «presse populaire » et une « presse de qualité », au public plus restreint mais bénéficiant d'une reconnaissance professionnelle plus grande. Le champ cinématographique tend de même à opposer un different levels: the level of the group (field, profession...) as a whole; that of the individuals within these groups; or that of the symbolic productions themselves.

Let us look, first of all, at the forms of institutional autonomy. In field theory, these constitute three dimensions, as Gisele Sapiro points out in her contribution: the appearance of a group of producers who specialize in the activity in question; the constitution of instances of specific consecration; and the formation of a market of symbolic goods (Bourdieu 1985). However, these dimensions vary depending on the activity, as shown by the various case studies compiled in this dossier. The markets associated with fields of symbolic production can be markets in the ordinary sense of the term (where a product with an associated monetary value is exchanged) or they can be understood in a more metaphorical sense. In contrast to literature, film, and journalism, scientific production relies, for example, very little on the sale of work. The term "market" can also be used to analyse non-monetary exchanges, such as in the religious field or "market of salvation goods" (Bourdieu 1971). Furthermore, even when the term "market" can be understood in its ordinary sensethat of the interaction of supply and demand-, markets of symbolic goods can be distinguished not only from one another, but also from markets of non-cultural goods. As Julien Duval's contribution shows, the autonomization of the fields of journalism and cinema, just like that of the literary field, manifests itself via the differentiation of a pole of restricted production in which the economic logic of the maximization of sales or profit cannot prevail. Thus, there is within the journalistic field an opposition between a "popular" and a "quality" press, whose audience is narrower but has greater professional recognition. The field of cinema similarly tends to pit "cinéma d'auteur" (sometimes called "independent cinema" or "art cinema" outside France), which is more orientated towards formal innovations, against "commercial cinema." While, as the article 
« cinéma commercial » et un « cinéma d'auteur » (« indépendant » ou « artistique » dans d'autres pays que la France), davantage tourné vers les innovations formelles. Si, comme le montre l'article, ces homologies tiennent en partie au fait que le champ littéraire a pu être délibérément pris pour modèle, les marchés cinématographique et journalistique n'en prennent pas moins des formes spécifiques que ce soit au niveau des barrières à l'entrée, des modalités de

financement, ou des rapports à l'État.

Comme le " marché ", les instances de consécration spécifiques prennent des formes différentes selon les espaces. Dans les champs qui ont atteint un certain degré d'autonomisation, elles sont multiples et concurrentes - une « institutionnalisation de l'anomie " que Pierre Bourdieu opposait au monopole de définition des critères d'appréciation artistique légitimes dont disposait l'Académie des beaux-arts (Bourdieu 1992). Dans le cas des champs littéraire cinématographique et artistique, le pouvoir de consécration est en outre partagé entre des producteurs ${ }^{4}$ et des critiques, dont les catégories de perception et d'évaluation ne sont pas nécessairement homologues. Jérôme Pacouret souligne ainsi le rôle des critiques dans le processus d'autonomisation du champ cinématographique et dans l'émergence de la catégorie d'auteur de film durant la première moitié du $x x^{e}$ siècle. En revanche, au sein des champs académique, scientifique ou journalistique, souvent plus professionnalisés, l'existence d'instances de consécrations spécifiques prend la forme du jugement des pairs, c'est-à-dire de l'évaluation des producteurs par d'autres producteurs (Lamont 2009, Aust 2014).

4. Le terme de « producteur » est employé ici dans un sens abstrait et général pour désigner les agents qui participent à la production de biens symboliques quels qu'ils soient (artistiques, théoriques, littéraires, etc.) shows, these similarities are partly linked to the fact that the literary field has deliberately been used as a model, the forms taken by the markets of cinema and journalism are still specific, whether in relation to entry barriers, methods of funding, or relationships to the State.

As it is the case with the "markets," the instances of specific consecration also take different forms in different spaces. Fields which have reached a high level of autonomy are characterized by multiple and rival instances of consecration. This "institutionalization of anomie" contrasts according to Bourdieu with the jurisdiction of the Académie des beaux-arts in the definition of legitimate criteria for artistic appreciation (Bourdieu 1996: 132). In the case of the literary, film, and artistic fields, the power of consecration is furthermore shared between producers ${ }^{4}$ and critics, whose categories of perception and assessment are not necessarily the same. Jérôme Pacouret emphasizes the role of critics in the process of autonomization of the field of cinema and in the emergence of the category of film author in the first half of the twentieth century. However, within the academic, scientific, or journalistic fields, which are often professionalized to a greater extent, the instances of specific consecration take the form of peer judgement-that is to say the evaluation of producers by other producers (Lamont 2009; Aust 2014)

4. The term "producer" is employed here in the abstract and general sense, to refer to agents that participate in the production of symbolic goods, whether these are artistic, theoretical, literary, etc. 
Inséparable des deux dimensions préalablement évoquées, la délimitation d'un corps de spécialistes passe notamment par la définition de barrières à l'entrée, allant de la détention de diplômes spécifiques (comme dans le cas des professions scientifiques) à des modalités de contrôle moins codifiées (comme dans le cas du champ littéraire, auquel l'appartenance est définie par le fait d'être publié) en passant par des cas intermédiaires comme celui du champ journalistique, doté d'écoles spécialisées mais continuant à valoriser fortement la formation « sur le tas » (Chupin 2018, Neveu 2009). Le développement professionnel des créateurs et créatrices de biens symboliques varie selon les champs (Sapiro 2006), les professions très institutionnalisées comme les scientifiques et les architectes contrastant avec le cas des artistes ou écrivain'e.s qui vivent très rarement de cette activité. L'autonomie d'un champ peut aussi être alimentée par des relations et luttes interprofessionnelles, comme celles portant sur l'exploitation des écrivains par les éditeurs et les patrons de presse (Bourdieu 1992). Dans ce numéro, Jérôme Pacouret montre que les disputes entre différents groupes de professionnels autour de la définition du statut d'auteur de cinéma ont contribué à l'autonomisation du cinéma par rapport à d'autres activités artistiques. Ces luttes ont aussi contribué à l'émergence d'une valeur cinématographique distincte de la popularité des films.

Comme le rappelle Julien Duval, l'autonomie - toujours relative d'un champ se mesure également à sa capacité à subordonner " le principe de hiérarchisation externe » au « principe de hiérarchisation interne » (Bourdieu 1992). Dans cette perspective, l'autonomie constitue un élément de différenciation à l'intérieur du champ, où des positions et logiques autonomes s'opposent aux logiques hétéronomes issues d'autres espaces sociaux (politique, religion, champ économique). L'autonomie d'un champ de production culturelle peut ainsi se mesurer à la coupure entre son pôle autonome et son pôle hétéronome (Bourdieu 1992). Dans ce numéro, Julien
Inseparable from the two previously mentioned dimensions, the demarcation of a body of specialists involves in particular the definition of entry barriers, from the requirement of specific qualifications (as in the case of science professions) to less codified methods of control (as in the case of the literary fieldbelonging to which is defined by the fact of being published) by way of cases that fall between the two, such as the journalistic field, which has specialized schools but continues to strongly favour "on the job" training (Chupin 2018; Neveu 2009). The professional development of the creators of symbolic goods varies according to the field (Sapiro 2006). Professions that are highly institutionalized such as researcher and architect contrast with the cases of artists and writers, who can rarely live off this activity alone. The autonomy of a field can also be fuelled by inter-professional relations and struggles, such as those concerning the exploitation of writers by publishers and press owners (Bourdieu 1996: 119). In this issue, Jérôme Pacouret shows that the battles to define the author of a film, which have pitted several professional groups against one another, have contributed to cinema's autonomization in relation to other artistic activities. The same battles have favoured the emergence of a cinematographic value that is distinct from boxoffice success.

As Julien Duval points out, the-always relative-autonomy of a field is also measured by its capacity to subordinate the "principle of external hierarchization" to the "principle of internal hierarchization" (Bourdieu 1996). Understood in this way, autonomy also constitutes an element of differentiation within a field where autonomous positions and logics confront heteronomous logics from other social spaces (politics, religion, or economic field). The autonomy of a field can thus be measured by the separation between its autonomous and heteronomous poles (Bourdieu 1996: 217). In this issue, Julien Duval notes, for instance, the weak autonomy 
Duval constate ainsi la faible autonomie des champs journalistique et cinématographique en observant les continuums entre leurs pôles autonomes et hétéronomes. Du point de vue de la méthode, l'analyse des correspondances multiples est un des moyens statistiques privilégiés pour mettre en évidence la coexistence de différentes formes de reconnaissance et de pouvoir. Les bases de données prosopographiques à partir desquelles ces analyses sont réalisées constituent à ce titre l'effort le plus conséquent pour définir l'autonomie et l'hétéronomie à l'aide d'une multiplicité d'indices (Bourdieu 1984 ; Duval 2006 ; Lebaron 2000 ; Poupeau 2003 ; Sapiro 1999). Variables selon les champs, les périodes et les populations considérés, ces indices ne se comprennent qu'en relation les uns avec les autres. Ainsi, les verdicts d'une même instance de consécration peuvent être des indicateurs d'autonomie ou d'hétéronomie selon les époques, comme dans le cas du prix littéraire français de l'académie Goncourt ou du prix Nobel de littérature, qui ont prêté une attention croissante à la popularité potentielle des œuvres et écrivain·e·s récompensé·e·s

(Casanova 1999 ; Sapiro 2016)

L'autonomie des espaces de production culturelle se mesure enfin au niveau des œuvres elles-mêmes et de leurs caractéristiques internes. Dans les approches en termes de champ, cette autonomie relative se manifeste par le fait que les forces et logiques extérieures (par exemple les considérations éthiques ou politiques) ne peuvent s'y exprimer qu'au prix d'un travail de mise en forme qui peut les rendre méconnaissables, comme le montre le cas de Martin Heidegger, analysé par Bourdieu (Bourdieu 1988). " Le champ exerce un effet de réfraction (à la façon d'un prisme) ", et son " "coefficient de réfraction" " mesure " son degré d'autonomie " (Bourdieu 1994 : 68). Des travaux ont montré, par exemple, comment la rigueur et la clarté, défendues au début du $\mathrm{xx}^{e}$ siècle par les philosophes du cercle de Vienne, ainsi que leur positivisme et leur critique de la métaphysique constituaient une réponse, sur le of the fields of journalism and cinema by observing the continuum between their autonomous and heteronomous poles. From a methodological point of view, correspondence analysis is one of the preferred statistical means of highlighting the coexistence of different forms of recognition and power. The prosopographic databases from which these analyses are carried out constitute the most significant effort to define autonomy and heteronomy using a multiplicity of indices (Bourdieu 1988; Duval 2006; Lebaron 2000; Poupeau 2003; Sapiro 2014). These indicators are always multiple, they vary over time and according to the fields and populations in question, and they can only be understood in relation with one another. Therefore verdicts of one instance of consecration may be indicators of autonomy or heteronomy according to time, such as in the case of the French literary prize of the Académie Goncourt or of the Nobel Prize for Literature, which have paid increasing attention to the potential popularity of winning works and writers (Casanova 1999; Sapiro 2016).

Finally, the autonomy of spaces of cultural production is measured against the works themselves and their internal characteristics. In approaches in terms of field, this relative autonomy is manifested in the fact that external forces and logics (for example, ethical or political considerations) can only be expressed in such a way that reshapes them, making them unrecognisable, as exemplified in Pierre Bourdieu's study of Martin Heiddegger (Bourdieu 1991). "The field exerts a refraction effect (much like a prism)," says Bourdieu, and its "refraction coefficient" measures "its degree of autonomy" (Bourdieu 1992). Studies have shown for example how the rigour and clarity defended at the beginning of the twentieth century by the philosophers known as the Vienna Circle, as well as their positivism and criticism of metaphysics, was a response, in the field of epistemology, to the conservatism of the German romantic 
terrain de l'épistémologie, au conservatisme de la droite romantique allemande, de la part de ces intellectuels majoritairement acquis aux idées sociales-démocrates (Collins 2009) ; ou comment la phénoménologie herméneutique de Paul Ricoeur retraduisait au sein du champ philosophique français d'après-guerre les engagements de celui-ci au sein du champ religieux, et notamment

l'existentialisme chrétien de sa jeunesse (Hauchecorne 2017)

Si elle est peut-être moins étudiée dans ce dossier, cette dimension de l'autonomie n'en est pas totalement absente pour autant. Plusieurs contributions permettent notamment de questionner le lien entre l'autonomie des champs de production culturelle et certaines croyances spécifiques qui lui sont classiquement associées comme la défense de l'art pour l'art, l'affirmation du primat de la forme, ou l'euphémisation des parti pris politiques. Gisèle Sapiro fait apparaître que la défense de l'art pour l'art affichée par La Nouvelle Revue française (NRF) durant l'Occupation n'était pas une marque d'autonomie mais visait au contraire à masquer le contrôle politique de cette revue littéraire, relancée par l'ambassadeur d'Allemagne Otto Abetz (Sapiro 1999). Flora Bajard explique que les céramistes d'art, en France, se sont autonomisés par rapport à la céramique industrielle en s'appuyant sur des croyances typiques des artistes, tout en refusant la distinction entre l'utile et le beau par laquelle a été définie l'activité artistique.

\section{L'autonomie entre État et champ économique}

En considérant les différentes manifestations de l'autonomie dans les domaines artistiques, culturels et intellectuels, les articles de ce dossier permettent également de s'interroger sur certaines conditions sociales de possibilité de l'autonomie. Les études réunies ici rappellent en particulier que toute intrusion de l'État ou du right, on the part of these intellectuals who were mainly committed to social-democratic ideas (Collins 2009); or how Paul Ricoeur's hermeneutic phenomenology was a refraction in the field of postwar French philosophy, of his commitment within the religious field and specifically the Christian existentialism of his youth (Hauchecorne 2018).

Although less studied in this dossier, this dimension of autonomy is not entirely absent. Several contributions to the dossier notably question the link between the autonomy of the fields of cultural production and some of the specific beliefs that are traditionally associated with it such as the defence of art for art's sake, the affirmation of the primacy of form, and the euphemizing of political bias. Gisèle Sapiro reveals that the defence of art for art's sake upheld by the Nouvelle Revue française during the Occupation was not a symptom of autonomy but instead sought to mask the political control of this literary review, as it was relaunched by the German ambassador Otto Abetz (Sapiro 2014). Flora Bajard demonstrates that artistic ceramists in France acquired their autonomy in relation to industrial ceramists by relying on beliefs typical of artists, while at the same time rejecting the distinction between function and beauty that defines artistic activity.

\section{Autonomy Between the State and the Economic Field}

In considering the various manifestations of autonomy in the artistic, cultural, and intellectual domains, the articles in this dossier also question some of the social conditions that enable autonomy. The studies brought together here point out in particular that not every intrusion by the State or the marketplace is necessarily 
marché n'est pas nécessairement synonyme d'hétéronomisation. En effet, les conditions de l'autonomie ne résident pas tant dans l'indépendance à l'égard des champs économiques et du pouvoir politique que dans un système de relations qui mettent ces interventions au service de l'autonomie.

Pour ce qui est du champ économique, plusieurs contributions à ce numéro rappellent ainsi le rôle de l'essor des marchés du livre et de l'art au XIX ${ }^{e}$ siècle dans l'autonomisation des champs littéraires et artistiques vis-à-vis de différentes formes de mécénats, de clientélisme ou de contrôle politique (Bourdieu 1971a ; 1992 ; 2013). De même, tout en excluant la quête de profits matériels à court terme, la logique de production et de diffusion " restreintes » des pôles autonomes des champs de production culturelle autorise ou implique, à long terme, la conversion du capital symbolique en argent (Bourdieu 1992). L'affirmation de logiques marchandes peut toutefois, à son tour, contrarier l'autonomie conquise contre la puissance politique. Julien Duval le souligne en revenant sur l'hétéronomie que fait peser l'attention accrue aux audiences sur le journalisme télévisé. Ces effets du marché tiennent pour partie à sa structure, comme l'expose Myrtille Picaud lorsqu'elle explique que la soumission des programmateurs et programmatrices des salles de concert aux verdicts économiques est favorisée par la concentration et l'intégration verticale de leur marché. Les coûts de production et de diffusion des œuvres peuvent être une autre contrainte économique restreignant l'autonomie d'une activité culturelle. Julien Duval souligne ainsi que le coût de production des films et des journaux oblige, toutes choses égales par ailleurs, à viser un large public et peut constituer un obstacle à l'affirmation d'une logique spécifique. À l'inverse, Myrtille Picaud montre comment le bas coût de l'immobilier à Berlin permet aux programmateurs des salles de concert de s'émanciper en partie des contraintes proprement économiques. Enfin, il est parfois possible de mettre des logiques hétéronomes au service de logiques autonomes. Certains artistes synonymous with a push towards heteronomy. The conditions for autonomy do not so much reside in independence with regard to the economic field and that of political power as in a system of relations that make these interventions work in favour of autonomy.

Regarding the economic field, several contributions to this issue reference the role of the growth in the nineteenth century of the book and art markets in the autonomization of the literary and artistic fields vis-à-vis different forms of sponsorship, patronage, and political control (Bourdieu 1985; 1996; 2017). Similarly, although excluding short-term economic profits, the logic of 'restricted' production and distribution which prevails at the autonomous poles of the fields of cultural production, authorizes or involves, on the long term, the conversion of symbolic capital into money (Bourdieu 1996). The assertion of these trade logics may nevertheless in turn upset the autonomy gained against political power. Julien Duval points this out by considering the heteronomy that the increased attention to audiences creates for television journalism. Such outcomes are due in part to the structure of the market, as Myrtille Picaud shows when she explains that the submission of music venue programmers to economic rules is encouraged by the concentration and vertical integration of their market. Another dimension relating to market structure is the extent of fixed costs that can also act as a brake on autonomy for cultural sectors. For instance, Julien Duval stresses that the production costs of films and newspapers oblige them, all things being equal, to target a broader audience and can constitute a barrier to the assertion of a specific logic. Conversely, Myrtille Picaud shows how the low cost of Berlin's real estate allows local music venue programmers to partly free themselves from strictly economic constraints. Finally, heteronomous logics can sometimes serve autonomous logics. Some film creators and production and distribution companies reconcile the logics of large 
et entreprises de production et de diffusion concilient les logiques de grande production et de production restreinte, par exemple en alternant des projets de films plus ou moins faciles à rentabiliser (de Verdalle 2013, Roussel 2017), ou en réunissant au sein d'un même catalogue ou d'une même programmation des œuvres et des artistes s'adressant à des publics de taille variée, comme le font des maisons d'édition et des salles de spectacle et de cinéma.

De même, l'intervention de la puissance publique peut renforcer ou freiner l'autonomie d'une activité culturelle. Certains champs de production culturelle se sont autonomisés par rapport à l'État. C'est le cas selon Bourdieu du champ artistique français au XIX ${ }^{\mathrm{e}}$ siècle, dont l'autonomie se conquiert vis-à-vis de l'Académie (Bourdieu 2013) - un point de vue qui fait toutefois l'objet de discussions (Sofio 2014). Mais avec la propagande, c'est certainement la censure qui constitue la forme d'hétéronomie d'État la plus radicale, comme dans les cas des cinémas iranien et soviétique mentionnés par Julien Duval, même si la censure cinématographique ne se rencontre pas uniquement dans les régimes autoritaires (sur le cas français, voir Meyer 2017). Réciproquement, comme cela a été souligné dans le cas du champ littéraire (Sapiro 2003), les politiques culturelles qui se sont institutionnalisées au $x x^{e}$ siècle ne peuvent être réduites à des sources d'hétéronomie et peuvent au contraire renforcer les logiques les plus spécifiques (Dubois 1999).

Les études réunies ici prennent en compte deux formes d'intervention publique affectant l'autonomie des activités littéraire et artistique. Premièrement, des normes juridiques peuvent être favorables aux logiques autonomes. L'article de Flora Bajard montre que la loi Pinel de 2014 a créé en France un cadre propice à l'affirmation des logiques spécifiques des céramistes d'art, qui luttaient depuis plusieurs décennies pour faire reconnaître le caractère original de leurs productions et s'émanciper des formes plus industrielles d'artisanat. and restricted production, for example by alternating the production of films of varying profitability (de Verdalle 2013; Roussel 2017), or by including different works and artists, addressing large or limited audiences, within the same catalogue or programme, just as publishing houses, concert venues, and cinemas do.

Similarly, the intervention of public authorities can also act as a brake on autonomy or, conversely, accelerate it. Some fields of cultural production have gained autonomy in relation to the State. According to Bourdieu, it is the case of the nineteenth-century French artistic field vis-à-vis the Academy (Bourdieu 2017), although this viewpoint has been challenged (Sofio 2014). State interference limits this autonomy even more dramatically when it takes the form of censorship or political control, as in the cases of Iranian or Soviet cinema mentioned by Julien Duval, though film censorship does not only occur in authoritarian regimes (on the French case, see Meyer 2017). However, as has been emphasized in the case of the literary field (Sapiro 2003), cultural politics, which was established within institutions in the twentieth century, cannot be reduced to sources of heteronomy and can, conversely, reinforce the most specific logics (Dubois 1999).

The studies brought together here take into account two forms of public intervention that affect the autonomy of literary and artistic activities. First, the law may favour autonomous logics. Flora Bajard's article shows how, in France, the Pinel law of 2014 created a framework conducive to the assertion of specific logics of artistic ceramists who have fought for several decades for the recognition of the original nature of their productions, so that they can break free from the most industrial forms of craft. The autonomy of an 
L'autonomie d'une activité est affectée par des normes juridiques visant le développement d'un marché et la professionnalisation de sa force de travail. C'est le cas du droit de propriété des œuvres, dont l'extension au cinéma a attisé les luttes de définition des auteurs de films et le processus d'autonomisation du cinéma étudiés ici par Jérôme Pacouret. Deuxièmement, l'État peut conforter des logiques autonomes en soutenant, au titre de leur valeur esthétique, culturelle ou scientifique, des créations faiblement rentables. Les contributions de Julien Duval, Sophie Noël et Myrtille Picaud décrivent plusieurs dispositifs d'aide qui, en France, bénéficient aux intermédiaires et producteurs aux logiques autonomes, tels que les subventions à des salles de musique, les labels et avantages fiscaux attribués à des librairies indépendantes, ou encore l'avance sur recettes et les aides au cinéma dit « d'art et d'essai » (Pinto 2014). Ces analyses peuvent être rapprochées des travaux consacrés au théâtre public, qui ont montré le rôle joué par le système de subventions publiques dans l'autonomisation et la reproduction de ce sous-champ de production restreinte (Glas 2018)

Ces aides ne sont bien sûr en mesure de conforter l'autonomie des espaces de production culturelle que si leurs critères d'attribution se rapprochent des catégories de jugement les plus spécifiques (celles des instances les plus autonomes), ce qui n'est pas nécessairement le cas. Certaines finalités et justifications des interventions publiques, comme la « démocratisation culturelle », obligent les producteurs et diffuseurs subventionnés à prendre en considération la taille et la diversité de leurs publics. L'attribution de ces aides peut en outre avoir des effets sur les rapports de force entre approches, écoles, esthétiques à l'intérieur des champs considérés. Les critères d'évaluation mis en œuvre peuvent ainsi épouser les catégories de jugement des agents ou des institutions les plus anciennement consacrés du pôle autonome et donc être peu profitables aux nouvelles avant-gardes ou aux activity is also affected by laws aimed at developing the market and professionalizing its labour force. This is the case regarding the right of ownership of works, the extension of which to cinema has fuelled the struggles to define film authors and the process of autonomization as studied by Jérôme Pacouret. Second, the State can reinforce autonomous logics by supporting scarcely profitable creations based on their aesthetic, cultural, or scientific value. As described in the contributions by Julien Duval, Sophie Noël, and Myrtille Picaud, several support schemes benefit French intermediaries and producers with autonomous perspectives, such as subsidies to music theatres, labels, tax advantages granted to independent bookshops, advances on income or the so-called art et essai cinema funding (Pinto 2014). These studies can be reconciled with work on public theatre that has shown the role played by the system of public subsidies in the autonomization and reproduction of this subfield of restricted production (Glas 2018).

Such support can of course only strengthen the autonomy of spaces of production if the criteria for receipt are close to the most specific categories of judgement (that is the categories of judgement associated with the most autonomous positions), which is not necessarily the case. Some aims and justifications for public interventions, such as "cultural democratization," force subsidized producers and distributors to consider the size and diversity of their audiences. The allocation of such aid may also affect the balance of power between approaches, schools, and aesthetics within the fields considered. The assessment criteria implemented may match the categories of judgement of the oldest consecrated agents or institutions of the autonomous pole, and therefore be of little use to the new avant-garde artists or entrants to the field. In France in the 1960s, the review Les Cahiers du cinéma criticized 
entrant·e.s au sein du champ. En France, dans les années 1960, la revue Les Cahiers du cinéma a reproché au Centre national du cinéma (CNC) de condamner certaines esthétiques et d'imposer aux réalisateurs et réalisatrices de la Nouvelle Vague des « alibis littéraires ou thématiques » (Gimello-Mesplomb 2003). Inversement, Julien Duval s'interroge ici sur la contribution de l'État au renforcement des contraintes économiques structurant le champ cinématographique au cours des dernières décennies. Toujours à propos de la France, si Sophie Noël souligne le rôle que les aides publiques ont joué dans le développement de l'édition indépendante, notamment par le financement des traductions, elle rappelle également que la majorité des aides du Centre national du livre (CNL) vont en priorité à de grandes maisons généralistes comme Gallimard et le Seuil. Pour toutes ces raisons, ces aides et leurs conditions d'attribution sont l'objet de luttes. Sophie Noël mentionne la contestation des commissions du CNL par des éditeurs et éditrices indépendant·es ; de même, Flora Bajard revient en détail sur les luttes engagées sur le terrain juridique par plusieurs céramistes d'art pour pouvoir bénéficier du régime de protection sociale des artistes plasticien.ne.s.

Plus généralement, les effets des interventions publiques sur l'autonomie des champs culturels se comprennent mieux si l'on cesse de les réifier en les attribuant à un État. Comme l'a montré Vincent Dubois, les politiques culturelles peuvent être analysées comme « le produit des rapports entre le champ de la culture et le groupe des agents administratifs et politiques qui, au sein de l'espace gouvernemental, interviennent sur les questions culturelles » (Dubois 1999 ; 2014). La contribution de Sophie Noël à ce dossier identifie ainsi divers acteurs et représentants du marché du livre cherchant à influencer les politiques culturelles en valorisant leur « indépendance ». the Centre national du cinéma for condemning certain aesthetics and imposing "literary or themed alibis" on the directors of the Nouvelle Vague (Gimello-Mesplomb 2003). Conversely, Julien Duval questions here the role of the State to the strengthening of the economic constraints structuring the film industry over the past decades. Still on the French case, while Sophie Noël emphasizes the role that public financial support has played in the development of independent publishing, especially through the funding of translations, she also points out that the majority of support from the Centre national du livre (CNL) goes primarily to the largest mainstream publishing companies such as Gallimard et Le Seuil. For all these reasons, this support and the conditions for its receipt are the object of struggles. Sophie Noël mentions certain independent publishers' dispute with the CNL commissions. Similarly, Flora Bajard discusses in detail the legal battles carried out by many artistic ceramists to benefit from the social protection regime for visual artists.

More broadly, the effects of public interventions on the autonomy of cultural fields are better understood if we stop reifying them by attributing them to a State. As Vincent Dubois has shown, cultural policies can be analysed as the "product of the relationship between the cultural field and the group of administrative and political agents who, within the governmental space, intervene on cultural issues" (Dubois 1999; 2014). That is why Sophie Noël's contribution to this dossier identifies various actors and representatives of the book market which seek to influence cultural policies by promoting their "independence." 
Structurée par des interventions d'État et par des contraintes de rentabilité communes à d'autres activités économiques, l'autonomie d'un champ de production culturelle dépend aussi de ses relations avec d'autres champs du même type, comme l'avait montré Pierre Bourdieu dans son analyse croisée de l'autonomisation des champs artistique et littéraire (Bourdieu 1992). De manière similaire, des travaux ont montré comment l'autonomisation du champ artistique a croisé celle du champ photographique (Roubert 2015). Dans ce dossier, les contributions de Julien Duval et de Jérôme Pacouret décrivent comment l'usage, dans les films, de conventions et d'œuvres littéraires ainsi que la conversion au cinéma d'écrivains et d'artistes ont favorisé l'autonomisation d'un champ cinématographique, qui a néanmoins dû affirmer sa spécificité pour être reconnu comme un art à part entière. Cela confirme que l'assimilation d'une activité à un art implique généralement des analogies avec d'autres activités artistiques et l'affirmation de sa spécificité par rapport à ces dernières (Heinich \& Shapiro 2012). Dans ce dossier, Flora Bajard analyse les relations de dépendance et de distinction des céramistes d'art par rapport aux artistes. L'autonomie d'un champ peut être entretenue par ses concurrences avec d'autres champs et par l'appropriation d'œuvres d'autres disciplines. Par exemple, la valorisation des infidélités des cinéastes aux livres qu'ils et elles adaptent et les moqueries adressées par des critiques de cinéma aux écrivain·e.s passé·e.s à la réalisation entretiennent l'idée d'une valeur cinématographique distincte de la valeur littéraire (Pacouret 2017).

Enfin plusieurs contributions font apparaître le caractère non linéaire, réversible et pluridimensionnel des processus d'autonomisation des champs culturels. Julien Duval, Myrtille Picaud et Sophie Noël montrent que l'autonomie du cinéma, de la musique et de l'édition est affectée par la concentration de leurs marchés au cours des dernières décennies - un processus à la fois encouragé et atténué
Structured by State interventions and the constraints of profitability common to other economic activities, the autonomy of a field of cultural production also depends on its relations with other fields of the same type, as Bourdieu showed in his cross-analysis of the autonomization of the artistic and literary fields (Bourdieu 1996). In a similar way, work has shown how the autonomization of the artistic field has overlapped that of the photographic field (Roubert 2015). The contributions of Julien Duval and Jerome Pacouret in this dossier similarly describe how the use in films of literary conventions and works as well as some writers' and artists' conversion to the cinema have encouraged the autonomization of the field of cinema, which has nevertheless had to affirm its originality in order to be recognized as an art in its own right. This confirms that when an activity becomes classed as an art, this generally involves analogies with other artistic activities and the assertion of its originality in relation to other arts (Heinich \& Shapiro 2012). In this dossier, Flora Bajard analyses relationships of dependency and distinction among artistic ceramists compared with artists. The autonomy of a field can be maintained through its competition with other fields and by the appropriation of works from other disciplines. For example, the evaluation of film-makers' lack of faithfulness to the books they adapt, and the scorn of cinema critics directed at writers turned directors maintain the idea of a cinematographic value that is distinct from literary value (Pacouret 2017).

Finally, several articles emphasise the non-linear, reversible and multidimensional nature of the processes of autonomization of cultural fields. Julien Duval, Myrtille Picaud, and Sophie Noël show that the autonomy of cinema, music, and publishing is impacted by the increasing concentration of their markets during recent decades-a process which has been both fostered and softened 
par diverses interventions publiques. Jérôme Pacouret constate que l'autonomisation du cinéma par rapport à d'autres arts a en partie été opérée via la valorisation de logiques commerciales, plutôt que par la seule célébration d'un " cinéma pur ». Comme l'analyse Flora Bajard, les relations entre les céramistes d'art et le champ artistique évoluent au fil de sollicitations de l'État aux issues incertaines. Ce dossier laisse néanmoins entière la question de savoir si l'autonomie de ces activité doit être défendue et à quel prix.

$$
\begin{array}{r}
\text { Jérôme Pacouret } \\
\text { Institut de recherche médias, cultures, communication } \\
\text { et numérique (IRMÉCCEN)/Centre européen de sociologie } \\
\text { et de science politique-Centre de sociologie européenne (Cessp-CSE)/ }
\end{array}
$$

Mathieu Hauchecorne Université Paris 8 - Centre de recherches sociologiques et politiques/Laboratoir théories du politique (Cresppa-Laptop)

\section{Références bibliographiques}

Akoun André \& Ansart Pierre (dir.) (1999). Dictionnaire de sociologie Paris, Seuil/Le Robert.

Aust Jérôme (dir.) (2014). « Financer la recherche sur projet. Figures historiques d'un dispositif de gouvernement » (dossier). Genèses, 94 : 2-6.

Boudon Raymond \& BourRICAUd François (dir.) (2011). Dictionnaire critique de la sociologie. Paris, Presses Universitaires de France.

Boudon Raymond, Besnard Philippe, Cherkaoul Mohamed, Lecuyer Bernard-Pierre (dir.) (1999). Dictionnaire de sociologie. Paris, Larousse.

BouRdieu Pierre (1971a). «Le marché des biens symboliques ». L'Année sociologique, $22: 49-126$. by various State interventions. Furthermore, Jérôme Pacouret notes that the autonomization of cinema in relation to other arts has partly been achieved through the endorsement of commercial logics, rather than through the mere celebration of "pure cinema." As Flora Bajard's analysis shows, the relations between artistic ceramists and the artistic field have evolved with State's requests, the outcomes of which are always uncertain. However, this dossie leaves open the question of whether the autonomy of these activities should be defended and at what cost.

Jérôme Pacouret

Institut de recherche médias, cultures, communication

et numérique (IRMÉCCEN)/Centre européen de sociologie

et de science politique-Centre de sociologie européenne (Cessp-CSE)/

Mathieu Hauchecorne

Université Paris 8 - Centre de recherches sociologiques et politiques/Laboratoire théories du politique (Cresppa-Laptop)

\section{References}

Akoun André \& Ansart Pierre (eds.) (1999). Dictionnaire de sociologie, Paris, Seuil/Le Robert.

Aust Jérôme (ed.) (2014). "Financer la recherche sur projet. Figures historiques d'un dispositif de gouvernement." Genèses, 94: 2-6.

Boudon Raymond \& Bourricaud François (eds.) (2011). Dictionnaire critique de la sociologie. Paris, PUF.

Boudon Raymond, Besnard Philippe, Cherkaoui Mohamed, Lecuyer Bernard-Pierre (eds.) (1999). Dictionnaire de sociologie, Paris.

Bourdieu Pierre (1971b). "Genèse et structure du champ religieux. » Revue française de sociologie 12(3): 295-334. 
BOURDieu Pierre (1971b). «Genèse et structure du champ religieux ». Revue française de sociologie 12(3) : 295-334.

Bourdieu Pierre (1984). Homo Academicus. Paris, Minuit.

Bourdieu Pierre (1988). L'Ontologie politique de Martin Heidegger. Paris, Minuit.

Bourdieu Pierre (1992). Les Règles de l'art. Genèse et structure du champ littéraire. Paris, Seuil.

Bourdieu Pierre (1994). «Pour une science des œuvres ». In Raisons pratiques, sur la théorie de l'action. Paris, Seuil : 59-97.

Bourdieu Pierre (1998). Contre-feux. Propos pour servir à la résistance contre l'invasion néolibérale. Paris, Raisons d'agir.

Bourdieu Pierre (2013). Manet. Une révolution symbolique. Paris, Seuil.

Bruce Steve \& YeARLey Steven (dir.) (2006). Sage Dictionary of Sociology. Londres, Sage publications.

Casanova Pascale (1999). La République mondiale des Lettres. Paris, Seuil.

Champy Florent (1996). « Les limites à l'autonomie de l'art dans les sociétés de type socialiste et de type capitaliste ». Revue française de sociologie, 37(4) : 625-635

Chupin Ivan (2018). Les Écoles de journalisme. Les enjeux de la scolarisation d'une profession. Rennes, Presses Universitaires de Rennes.

Collins Randall (2009). The Sociology of philosophies. Cambridge, Harvard University Press.
BouRdiEu Pierre (1985). "The market of symbolic goods." Translated by Rupert Swyer. Poetics, 14(1-2): 13-44.

Bourdieu Pierre (1988). Homo Academicus. Translated by Peter Collier. Palo Alto, Stanford University Press.

Bourdieu Pierre (1991). The Political Ontology of Martin Heidegger. Translated by Peter Collier. Palo Alto, Stanford University Press.

Bourdieu Pierre (1992). "Principles for a Sociology of Cultural Works." In Kemal Salim, Gaskell Ivan (eds). Explanation and Value in the Arts. Cambridge, Cambridge University Press.

BOURDIEU Pierre (1996). The Rules of Art. Genesis and Structure of the Literary Field. Translated by Susan Emanuel. Palo Alto, Stanford University Press.

Bourdieu Pierre (1998). Contre-feux. Propos pour servir à la résistance contre l'invasion néolibérale, Raisons d'agir.

Bourdieu Pierre (2017). Manet. A Symbolic Revolution. Transleted by Peter Collier and Margaret Rigaud-Drayton. Cambridge, Polity.

Bruce Steve \& YeARLEy Steven (eds.) (2006). Sage Dictionary of Sociology. London, Sage publications.

Casanova Pascale (1999). The Word Republic of Letters. Translated by Malcolm B. DeBevoise. Cambridge, Harvard University Press.

CHAMPy Florent (1996). "Les limites à l'autonomie de l'art dans les sociétés de type socialiste et de type capitaliste." Revue française de sociologie 37(4). 625-635.

ChupIN Ivan (2018). Les Écoles de journalisme. Les enjeux de la scolarisation d'une profession. Rennes, Presses Universitaires de Rennes. 
DuвoIs Vincent (1999). La Politique culturelle. Genèse d'une catégorie d'intervention publique. Paris, Belin.

DuBoIs Vincent (2014). « L'action de l'État, produit et enjeu des rapports entre espaces sociaux ». Actes de la recherche en sciences sociales, 201-202 : 11-25.

DuVAL Julien (2006). « L'art du réalisme. Le champ du cinéma français au début des années 2000 ». Actes de la recherche en sciences sociales, 161-162: 96-115.

Duval Julien (2016). Le Cinéma au xxe siècle. Entre loi du marché et règles de l'art. Paris, CNRS Éditions.

Fortier Michaël (2015). «Autonomie ». In Glinoer Anthony \& Saint-Amand Denis (dir.). Le lexique socius. [En ligne] [consultée le 17 octobre 2018].

Gimello-Mesplomb Frédéric (2003). " Le prix de la qualité. L'État et le cinéma français (1960-1965) ». Politix, 16 : 95-122.

GLAs Marjorie (2018). « Le populaire et le singulier. La singularité de l'acte créateur face au rôle social du théâtre (1945-1980) ». Tracés, 34 : 25-46. Gould Julius \& Kolb William (dir.) (1964). Dictionnary of the Social Sciences. Glencoe, Free Press of Glencoe.

HAUCHECORNe Mathieu (2017). « Un néo-personnalisme transatlantique? La lecture par Paul Ricœur des philosophies rawlsienne et postrawlsiennes ». Raisons politiques, 67 : 95-118.

HeINICH Nathalie \& ShapIRo Roberta (dir.) (2012). De l'artification. Enquêtes sur le passage à l'art. Paris, Éditions de l'EHESS.

Krefa Abir (2013). " La quête de l'autonomie littéraire en contexte autoritaire : le cas des écrivains tunisiens ». Sociologie, 4(4) : 395-411. LAMONT Michèle (2009). How professors think. Cambridge, Harvard University Press.
Collins Randall (2009). The Sociology of Philosophies. Cambridge, Harvard University Press.

Dubois Vincent (1999). La Politique culturelle. Genèse d'une catégorie d'intervention publique. Paris, Belin.

Dubois Vincent (2014). “L'action de l'État, produit et enjeu des rapports entre espaces sociaux." Actes de la recherche en sciences sociales, 201-202: 11-25.

Duval Julien (2006). "L'art du réalisme. Le champ du cinéma français au début des années 2000." Actes de la recherche en sciences sociales, 161-162: 96-115.

Duval Julien (2016). Le Cinéma au xx siècle. Entre loi du marché et règles de l'art: Entre loi du marché et règles de l'art. Paris, CNRS Éditions.

Fortier Michaël (2015). "Autonomie.” In Glinoer Anthony \& Saint-Amand Denis (eds.). Le Lexique socius. [Online] [accessed on 17 October 2018]

Gimello-Mesplomb Frédéric (2003). “Le prix de la qualité. L'État et le cinéma français (1960-1965)." Politix, 16: 95-122.

Glas Marjorie (2018). "Le populaire et le singulier. La singularité de l'acte créateur face au rôle social du théâtre (1945-1980)." Tracés, 34: 25-46.

Gould Julius \& Kolb William (eds.) (1964). Dictionnary of the Social Sciences. Glencoe, Free Press of Glencoe.

Hauchecorne Mathieu (2017). "Un néo-personnalisme transatlantique? La lecture par Paul Ricœur des philosophies rawlsienne et post-rawlsiennes." Raisons politiques, 67: 95-118.

Heinich Nathalie \& Shapiro Roberta (eds.) (2012). De l'artification Enquêtes sur le passage à l'art. Paris, Éditions de l'EHESS. 
LAtour Bruno (1984). Les Microbes, guerre et paix. Métailié, Paris. Lebaron Frédéric (2000). La Croyance économique. Les économistes entre science et politique. Paris, Seuil.

Moulin Raymonde (1969). «Art et société industrielle capitaliste. L'un et le multiple ». Revue française de sociologie, 10(1) : 687-702.

NeVeu Erik (2009). Sociologie du journalisme. Paris, La Découverte.

Pacouret Jérôme (2017). « Les écrivain·e·s dans la division du travail cinématographique ». In SAPIRo Gisèle \& RaBot Cécile (dir.), Profession? Écrivain. Paris, CNRS Éditions :125-148.

PINTo Aurélie (2014). « L'art et essai ou la politique de la qualité dans les salles de cinéma (1949-1961) ». In VeYroglou Dimitri (dir.). Le Cinéma ? Une affaire d'État (1945-1970). Paris, La Documentation française : 185-194.

Poupeau Franck (2003). Une sociologie d'État. L'école et ses experts en France. Paris, Raisons d'agir.

RAYNAUD Dominique (1999). « L'émergence d'une sociologie des œuvres : une évaluation critique ». Cahiers internationaux de sociologie, $106: 119-143$.

Roubert Paul-Louis (2015). « La critique de la photographie ou la genèse du discours photographique dans la critique d'art, 1839-1859 ». Sociétés \& Représentations, $40: 201-219$.

Roussel Violaine (2017). Representing Talent. Hollywood Agents and the Making of Movies. Chicago, University of Chicago Press.

SAPIRO Gisèle (1999). La Guerre des écrivains (1940-1953). Paris, Fayard. SAPIRO Gisèle (2003). "The literary field between the state and the market ». Poetics, $31: 441-464$.

SAPIRO Gisèle (2006). « Les professions intellectuelles entre l'État, l'entrepreneuriat et l'industrie ». Le Mouvement social, 214 : 3-24.
Krefa Abir (2013). "La quête de l'autonomie littéraire en contexte autoritaire: le cas des écrivains tunisiens." Sociologie, 4(4): 395-411.

Lamont Michèle (2009). How Professors Think. Cambridge, Harvard University Press.

Latour Bruno (1988). The Pasteurization of France. Translated by Alan Sheridan and John Law. Cambridge, Harvard University Press.

Lebaron Frédéric (2000). La Croyance économique. Les économistes entre science et politique. Paris, Seuil.

Moulin Raymonde (1969). "Art et société industrielle capitaliste. L'un et le multiple." Revue française de sociologie, 10(1): 687-702.

Neveu Erik (2009). Sociologie du journalisme. Paris, La Découverte.

PAcouret Jérôme (2017). "Les écrivain·e·s dans la division du travail cinématographique." In Sapiro Gisèle \& Rabot Cécile (eds.). Profession ? Écrivain. Paris, CNRS Éditions:125-148.

PINTO Aurélie (2014). "L'art et essai ou la politique de la qualité dans les salles de cinéma (1949-1961)." In Veyroglou Dimitri (ed.). Le Cinéma. Une affaire d'État (1945-1970). Paris, La Documentation française: 185-194.

Poupeau Franck (2003). Une Sociologie d'État. L'école et ses experts en France. Paris, Raisons d'agir.

RaYNAUD Dominique (1999). "L'émergence d'une sociologie des œuvres: une évaluation critique." Cahiers internationaux de sociologie, 106: 119143.

Roubert Paul-Louis (2015). "La critique de la photographie ou la genèse du discours photographique dans la critique d'art, 1839-1859." Sociétés \& Représentations, 40: 201-219. 
SAPIRO Gisèle (2009). « Modèles d'intervention politique des intellectuels. Le cas des écrivains ». Actes de la recherche en sciences sociales, 176$177: 8-31$.

SAPIRO Gisèle (2013). « Le champ est-il national ? ». Actes de la recherche en sciences sociales, $200: 70-85$

SAPIRO Gisèle (2016). « The metamorphosis of modes of consecration in the literary field : Academies, literary prizes, festivals ». Poetics, 59.

Sofio Séverine (2014). « Manet », Sociologie, comptes rendus. [En ligne] [consulté le 26 janvier 2019].

SofIO Séverine (2016). Artistes femmes. La parenthèse enchantée, XVIII $\mathrm{xI} \mathrm{x}^{e}$ siècles. Paris, CNRS Éditions.

Verdalle de Laure (2013). « Financer le cinéma ». In Rot Gwenaële \& Verdalle de (dirs.). Le Cinéma, travail et organisation. Paris, La Dispute.

Viala Alain (1985). Naissance de l'écrivain. Sociologie de la littérature à l'âge classique. Paris, Minuit.
RousseL Violaine (2017). Representing Talent. Hollywood Agents and the Making of Movies. Chicago, University of Chicago Press.

SAPIRO Gisèle (2003). "The literary field between the state and the market." Poetics, 31: 441-464.

SAPIRO Gisèle (2006). "Les professions intellectuelles entre l'État, l'entrepreneuriat et l'industrie." Le Mouvement social, 214: 3-24.

SAPIRO Gisèle (2009). "Modèles d'intervention politique des intellectuels. Le cas des écrivains." Actes de la recherche en sciences sociales, 176177: 8-31.

SAPIRo Gisèle (2013). "Le champ est-il national ?" Actes de la recherche en sciences sociales, 200: 70-85.

SAPIRO Gisèle (2014). The French Writers' War, 1940-1953. Translated by Vanessa Doriott Anderson and Dorrit Cohn. Durham, Duke University Press.

SAPIRO Gisèle (2016). "The metamorphosis of modes of consecration in the literary field: Academies, literary prizes, festivals." Poetics 59.

SoFIo Séverine (2014). "Manet." Sociologie, comptes rendus. [On line] [accessed on 26 January 2019].

SofIO Séverine (2016). Artistes femmes. La parenthèse enchantée, XVIII$x I x^{e}$ siècles. Paris, CNRS Éditions.

Verdalle de Laure (2013). "Financer le cinéma." In Rot Gwenaële \& Verdalle de Laure (eds.). Le Cinéma, travail et organisation. Paris, La Dispute.

Viala Alain (1985). Naissance de l'écrivain. Sociologie de la littérature à l'âge classique. Paris, Minuit. 